\title{
ANALISIS PERSEDIAAN OBAT DENGAN MENGGUNAKAN METODE ABC DAN ECONOMIC ORDER QUANTITY (EOQ) DI PT. DAYA MUDA AGUNG
}

\author{
Karmandito Kresna Saputra $^{1}$, Muhammad Marsudi ${ }^{1}$, Yassyir Maulana ${ }^{1}$ \\ ${ }^{1}$ Teknik Industri, Fakultas Teknik, Universitas Islam Kalimantan Muhammad Arsyad Al-Banjari \\ Jl. Adhyaksa, J1. Kayu Tangi 1 Jalur 2 No.2, Sungai Miai, Kec. Banjarmasin Utara, Kota Banjarmasin, \\ Kalimantan Selatan 70123 \\ Email : kresnasaputra8661@gmail.com
}

\begin{abstract}
Abstrak- Persediaan barang dimaknai sebagai barang yang diperoleh perusahaan buat dijual kembali atau diolah lebih lanjut dalam rangka menjalankan kegiatan perusahaan. Tanpa adanya persediaan, perusahaan akan dipertemukan pada suatu resiko dimana perusahaan mengalami kendala karena tidak dapat memenuhi keinginan pelanggan yang membutuhkan barang maupun jasa yang dihasilkan oleh perusahaan tersebut. PT. Daya Muda Agung yaitu sebuah perusahaan farmasi yang bergerak di bidang distribusi obat yang mendistribusikan ke berbagai rumah sakit atau apotik. Dari kegiatan distribusi yang dilakukan perusahaan, ditemukan beberapa jenis obat yang mengalami kelebihan persediaan hingga berdampak pada kadaluarsa. Pengendalian persediaan obat bertujuan buat menciPT.akan keseimbangan antara persediaan dengan permintaan. Buat itu, perusahaan harus memliki suatu metode perencanaan dan pengendalian persediaan obat. Bagian dari metode tersebut dikenal dengan Economic Order Quantity (EOQ). Economic Order Quantity (EOQ) yakni metode manajemen persediaan yang menentukan jumlah pemesanan/pembelian yang harus dilakukan dan berapa banyak jumlah yang harus dipesan agar biaya total (penjumlahan antara biaya pemesanan dan biaya penyimpanan) menjadi minimum. Perencanaan persediaan obat pada PT. Daya Muda Agung memakai metode Economic Order Quantity (EOQ), merubah beberapa kebijakan perusahaan terhadap jumlah pemesanan obat, diketahui total biaya pemesanan obat dari kebijakan perusahaan yaitu sebesar Rp 8.955.447.782 sedangkan total biaya pemesanan dari hasil penelitian yaitu sebesar $R p$ 8.659.305.844, selisih dari total biaya tersebut yaitu sebesar Rp 296.141.938.
\end{abstract}

Kata Kunci : ABC, Economic Order Quantity, Persediaan Obat

\section{PENDAhuluan}

$\mathrm{M}$ asalah persediaan yakni masalah yang sangat penting bagi sebuah perusahaan. Tanpa adanya persediaan, perusahaan akan dipertemukan pada suatu resiko dimana perusahaan mengalami kendala karena tidak dapat memenuhi keinginan pelanggan yang membutuhkan barang maupun jasa yang dihasilkan oleh perusahaan tersebut. Akan tetapi persediaan dapat menimbulkan banyak biaya penyimpanan (seperti biaya pegawai, biaya operasional pabrik, biaya gedung, dll). Karena itulah persediaan hanya diadakan apabila keuntungan yang diharapkan dari persediaan tersebut lebih besar daripada biaya-biaya yang ditimbulkan.

Persediaan barang dimaknai sebagai barang yang diperoleh perusahaan buat dijual kembali atau diolah lebih lanjut dalam rangka menjalankan kegiatan perusahaan. Perusahaan yang dapat mengendalikan sistem persediaannya dengan tepat akan memudahkan perusahaan buat bertahan dalam kegiatan operasional dan menjaga kelancaran operasi perusahaan. Buat itu persediaan barang menjadi hal yang penting, sebab sukses tidaknya perencanaan dan pengawasan persediaan akan berpengaruh besar terhadap keberhasilan suatu perusahaan, bagian darinya pada penentuan keuntungan perusahaan [6].

PT. Daya Muda Agung yaitu sebuah perusahaan farmasi yang bergerak di bidang distribusi obat yang mendistribusikan ke berbagai rumah sakit atau apotik. Dari kegiatan distribusi yang dilakukan perusahaan, ditemukan beberapa jenis obat yang mengalami kelebihan persediaan hingga berdampak pada kadaluarsa. Jika perusahaan mengalami kelebihan persediaan maka dapat merugikan, karena menyebabkan terhentinya perputaran uang atau modal dan munculnya biaya-biaya tambahan yang tidak diperlukan.

Berdasarkan uraian di atas, perusahaan harus memliki suatu metode perencanaan dan pengendalian persediaan obat. Bagian dari metode tersebut dikenal dengan Economic Order Quantity (EOQ). Economic Order Quantity (EOQ) yakni metode manajemen persediaan yang menentukan jumlah pemesanan/pembelian yang harus dilakukan dan berapa banyak jumlah yang harus dipesan agar biaya total(penjumlahan antara biaya pemesanan dan biaya penyimpanan) menjadi minimum.

Buat mencapai efisiensi, distribusi obat perlu dikelola dalam semua aspek buat mengatasi kelebihan stok, kadaluwarsa, rantai pasokan dan lain-lain. Pengendalian persediaan obat bertujuan buat menciptakan keseimbangan antara persediaan dengan permintaan. Fungsi pengendalian sangat penting buat menjamin efekfitas dan efisiensi pengelolaan persediaan obat itu sendiri. Tujuan dari pengendalian persediaan obat yang lain yaitu buat membuat persediaan yang dapat meminimalkan nilai dan kejadian stock out, hal ini tidak boleh disamakan dengan meminimalkan persediaan. Persediaan obat yang terlalu banyak akan memerlukan tempat serta biaya penyimpanan yang besar dan barang yang tersimpan tersebut yakni modal yang perputarannya berhenti. Sedangkan, jika terlalu sedikit kemungkinan akan ada permintaan yang tidak terpenuhi karena persediaan mengalami stockout sehingga berakibat pada merosotnya mutu pelayanan rumah sakit khususnya instalasi farmasi.

Dari beberapa penelitian mengenai perencanaan persediaan terdapat beberapa macam metode buat menyelesaikan masalah tersebut. Menurut penelitian [15], memakai metode EOQ Multi Item buat menentukan periode pemesanan obat yang optimum, sehingga didapatkan total cost usulan lebih rendah $2,4 \%$ dibandingkan total cost rencana aktual perusahaan. Sedangkan penelitian [6], memakai metode Economic Order Quantity (EOQ) dengan algoritma genetika buat mengatasi masalah persediaan barang pada PT. XYZ. Dengan demikian PT. XYZ dapat 
mengetahui berapa jumlah pemesanan (order quantity) barang A dan kapan seharusnya PT. XYZ melakukan pemesanan kembali barang A sehingga dapat mengoptimalkan biaya persediaan yang harus dikeluarkan buat barang A.

Berbeda dari jurnal yang telah dijelaskan sebagai acuan penelitian ini lebih umumnya memakai metode Economic Order Quantity (EOQ) buat memperhitungkan total cost sedangkan penelitian ini dilakukan di PT. Daya Muda Agung memakai metode analisis $\mathrm{ABC}$ buat mengklasifikasikan jenis obat. Penggunaan metode ABC secara efektif dapat membantu perusahaan dalam membuat perencanaan obat dengan mempertimbangkan aspek pemakaian dan nilai investasi. Klasifikasi ini akan sangat diperlukan buat variasi obat yang cukup luas, sehingga akan mempermudah dalam sistem pencatatan dan pelaporannya, kemudian memakai metode Economic Order Quantity (EOQ) buat mendapatkan jumlah pemesanan yang optimum, dan Reorder Point (ROP) buat menentukan waktu pemesanan yang optimal buat pembelian obat.

\section{METODE PENELITIAN}

Buat melaksanakan penelitian ini, dipakai tiga metode dalam proses pengambilan data, yaitu:Interview(wawancara) Sebuah metode yang dilakukan dengan cara menanyakan pertanyaan-pertanyaan secara langsung terhadap pihak perusahaan terkait buat memperoleh data dan informasi yang dibutuhkan. Wawancara yang dilakukan yaitu buat mengetahui proses bisnis perusahaan dan metode yang dipakai oleh perusahaan dalam perencanaan persediaan.Dokumentasi buat dapat memperoleh data yang dibutuhkan, metode dokumentasi dapat dipakai agar penulis dapat memiliki dokumen yang konkrit buat mendukung penelitian ini.Observasi Sebuah metode pengamatan yang dilakukan secara langsung terhadap sistem dan keadaan sebenarnya.

Langkah-langkah yang dilakukan dalam penelitian ini sebagai berikut.

1. Studi Lapangan

2. Identifikasi Masalah

3. Perumusan Masalah

4. Penentuan Tujuan Penelitian

5. Pengumpulan Data

6. Pengolahan Data

7. Analisa dan Pembahasan

8. Kesimpulan dan saran

\section{HASIL DAN PEMBAHASAN}

Data-data yang dipakai yaitu data pembelian dan permintaan obat bulan Januari-Mei 2021, data harga obat, data lead time pemesanan obat, biaya pemesanan obat dan biaya penyimpanan obat. Adapun data yang dikumpulkan dalam melakukan penelitian ini yaitu sebagai berikut:

1. Data Permintaan Obat di PT. Daya Muda Agung Berikut yakni sebagian data permintaan obat dan harga obat pada bulan Januari - Mei 2021.

Tabel 1. Klasifikasi Metode ABC

\begin{tabular}{|c|c|c|c|c|c|c|c|}
\hline No & Nama & $\begin{array}{l}\text { Harga } \\
\text { satuan }\end{array}$ & Jumlah & Total & $\begin{array}{c}\text { Nilai } \\
\text { kumulatif }\end{array}$ & Persentase & \\
\hline 1 & samcodin & 38.600 & 24.174 & 933.116 .400 & 933.116 .400 & 10 & A \\
\hline 2 & bet. obat kumur $190 \mathrm{ml} \mathrm{n}$ & 27.000 & 32.553 & 878.931 .000 & 1.812 .047 .400 & 19 & A \\
\hline 3 & omeprazole inj 40mg10vial & 250.000 & 3.059 & 764.750 .000 & 2.576 .797 .400 & 27 & A \\
\hline 4 & purifyng neem mask $100 \mathrm{ml}$ & 30.053 & 20.526 & 616.867 .878 & 3.193 .665 .278 & 34 & A \\
\hline 5 & rohto cool $7 \mathrm{ml}$ & 13.320 & 43.419 & 578.341 .080 & 3.772 .006 .358 & 40 & A \\
\hline 6 & counterpain cream $15 \mathrm{gr}$ & 21.800 & 21.482 & 468.307 .600 & 4.240 .313 .958 & 45 & A \\
\hline 7 & tempra drops $15 \mathrm{ml}$ new pck & 41.500 & 9.426 & 391.179 .000 & 4.631 .492 .958 & 49 & A \\
\hline 8 & movibet infus $400 \mathrm{mg}$ & 250.000 & 1.562 & 390.500 .000 & 5.021 .992 .958 & 53 & A \\
\hline 9 & sanmol syrup $60 \mathrm{ml}$ & 11.700 & 31.061 & 363.413 .700 & 5.385 .406 .658 & 57 & A \\
\hline 10 & betadine sol $5 \mathrm{ml} \mathrm{n}$ & 4.450 & 81.134 & 361.046 .300 & 5.746 .452 .958 & 61 & A \\
\hline 11 & counterpain cream $30 \mathrm{gr}$ & 34.900 & 9.897 & 345.405 .300 & 6.091 .858 .258 & 65 & A \\
\hline 12 & purifyng nem facewsh100ml & 30.053 & 9.602 & 288.568 .906 & 6.380 .427 .164 & 68 & A \\
\hline 13 & pepzol vial $40 \mathrm{mg}$ & 140.000 & 2.028 & 283.920 .000 & 6.664 .347 .164 & 71 & A \\
\hline 14 & komix jeruk nipisgformula & 34.545 & 6.478 & 223.782 .510 & 6.888 .129 .674 & 73 & B \\
\hline 15 & pepzol 20mg 10 tablet & 130.000 & 1.664 & 216.320 .000 & 7.104 .449 .674 & 75 & B \\
\hline 16 & vitabumin $130 \mathrm{ml}$ & 50.909 & 3.916 & 199.359 .644 & 7.303 .809 .318 & 78 & B \\
\hline 17 & tempra syr $60 \mathrm{ml}$ new pack & 36.800 & 5.524 & 203.283 .200 & 7.507 .092 .518 & 80 & $\mathrm{~B}$ \\
\hline 18 & sanmol drop $15 \mathrm{ml}$ & 15.700 & 11.804 & 185.322 .800 & 7.692 .415 .318 & 82 & B \\
\hline 19 & combantrin orange $10 \mathrm{ml}-\mathrm{fb}$ & 15.350 & 11.964 & 183.647 .400 & 7.876 .062 .718 & 84 & B \\
\hline 20 & citicoline $500 \mathrm{mg}$ 30kaplet & 180.000 & 974 & 175.320 .000 & 8.051 .382 .718 & 86 & B \\
\hline 21 & pepzol 40mg 10 tablet & 170.000 & 1.026 & 174.420 .000 & 8.225 .802 .718 & 87 & B \\
\hline 22 & counterpain cream $60 \mathrm{gr}$ & 62.600 & 2.490 & 155.874 .000 & 8.381 .676 .718 & 89 & B \\
\hline
\end{tabular}




\begin{tabular}{|l|l|c|c|c|c|c|c|}
23 & counterpain cream 120 gr & 89.300 & 1.620 & 144.666 .000 & 8.526 .342 .718 & 91 & $\mathrm{C}$ \\
\hline 24 & combantrin 250mg(mcrt)2s & 13.150 & 10.454 & 137.470 .100 & 8.663 .812 .818 & 92 & $\mathrm{C}$ \\
\hline 25 & dramamine 100 tablet & 169.000 & 792 & 133.848 .000 & 8.797 .660 .818 & 93 & $\mathrm{C}$ \\
\hline 26 & komix jahe g-formula & 34.545 & 3.697 & 127.712 .865 & 8.925 .373 .683 & 95 & $\mathrm{C}$ \\
\hline 27 & komix peppermint gformula & 34.545 & 3.665 & 126.607 .425 & 9.051 .981 .108 & 96 & $\mathrm{C}$ \\
\hline 28 & tempra syrup $30 \mathrm{ml}$ & 19.200 & 6.756 & 129.715 .200 & 9.181 .696 .308 & 98 & $\mathrm{C}$ \\
\hline 29 & etanyl $0.05 \mathrm{mg} / \mathrm{ml} 2 \mathrm{ml}$ & 185.000 & 640 & 118.400 .000 & 9.300 .096 .308 & 99 & $\mathrm{C}$ \\
\hline 30 & sammoxin fk 500 mg & 43.560 & 2.637 & 114.867 .720 & 9.414 .964 .028 & 100 & $\mathrm{C}$ \\
\hline & total & & 366.024 & 9.414 .964 .028 & & & \\
\hline
\end{tabular}

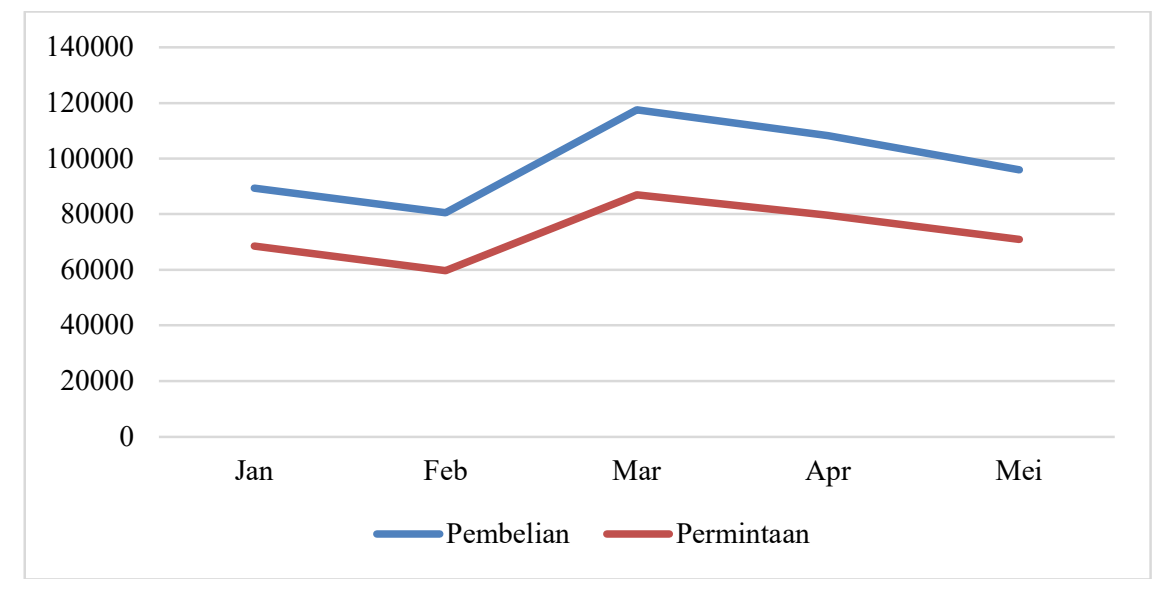

Gambar 1. Perbandingan Pembelian dan Permintaan

\section{Data Lead Time}

Pada penelitian ini waktu yang dibutuhkan oleh perusahaan selama proses pemesanan obat sampai datangnya obat ke perusahaan didefinisikan sebagai Lead Time. Menurut informan lead time/waktu tunggu pemesanan obat paling lama yaitu 9 hari.

3. Data Biaya

\section{a. Data Biaya Pemesanan}

Proses pemesanan yang dilakukan oleh perusahaan dimulai dari penempatan pemesanan hingga tersedianya barang tersebut di perusahaan, buat melakukkan proses tersebut maka perusahaan butuh mengeluarkan sejumlah biaya yang disebut sebagai biaya pemesanan. Dengan demikian biaya pemesanan yang ditanggung oleh perusahaan yaitu sebagai berikut:

1) Biaya telepon + internet

Dalam melakukan pemesanan, perusahaan melakukan telepon buat memeriksa ketersediaan obat, dan memastikan kesanggupan supplier buat dapat mengirimkan obat sesuai dengan waktu yang dibutuhkan oleh perusahaan. Perusahaan mengasumsikan bahwa penggunaan internet dalam proses pemesanan obat memakan persentase sebesar $10 \%$ dari biaya internet tiap bulannya.

Biaya internet $\quad=\operatorname{Rp} 493.900 \times 10 \%$

$$
=\operatorname{Rp} 49.390
$$

2) Biaya Pengiriman

Biaya pengiriman yang dikeluarkan perusahaan buat mendatangkan obat dari supplier yaitu sebesar $0,7 \%$ dari harga pembelian obat. Sebagai contoh buat obat SAMCODIN dengan harga satuan Rp 38.600 dan jumlah yang dipesan buat bulan Januari yaitu sejumlah 5.405, maka diperoleh:

$$
\begin{aligned}
\text { Biaya Pembelian } & =\operatorname{Rp} 38.600 \times 5.405 \\
& =\operatorname{Rp} 208.633 .000 \\
\text { Biaya Pengiriman } & =\operatorname{Rp} 208.633 .000 \times 0,7 \% \\
& =\operatorname{Rp} 1.460 .431
\end{aligned}
$$

3) Biaya Cetak

Biaya cetak yaitu biaya yang dikeluarkan perusahaan buat melakukan cetak bukti pembayaran buat dikirimkan via email ke setiap supplier dan bukti pemesanan yang akan ditunjukkan kepada kurir dari supplier. Buat kebutuhan ini setiap bulannya perusahaan akan membeli kertas sebanyak 2 rim dengan harga $\mathrm{Rp} 45.000$

Biaya cetak $=\operatorname{Rp} 2 \times 45.000 \times(2 / 500)$ lembar

$$
=\operatorname{Rp} 360
$$

Jadi total biaya pemesanan yang dibutuhkan buat setiap 1 kali pemesanan obat SAMCODIN yaitu Rp $49.390+\mathrm{Rp}$ $1.460 .431+\operatorname{Rp} 360=\operatorname{Rp} 1.510 .181$.

\section{b. Data Biaya Penyimpanan}

Berdasarkan informasi yang didapat, PT. Daya Muda Agung mengeluarkan biaya penyimpanan pertahun dalam persen antara lain:

1) Biaya kerusakan dan resiko lainnya :

Biaya penyimpanan yang akan menjadi tanggungan perusahaan yaitu resiko kerusakan barang dalam penyimpanan, resiko kehilangan, dan resiko kadaluwarsa. PT. Daya Muda Agung mengambil kebijakan buat menetapkan biaya kerusakan dan resiko lainnya sebesar $0,56 \%$ dari harga beli obat. 
2) Biaya asuransi

Perusahaan menetapkan biaya asuransi sebesar $0,6 \%$ dari harga beli yang dikeluarkan buat menyiapkan obat tersebut hingga siap dipasarkan.

Total persentase biaya penyimpanan yaitu $1,16 \%$.

4. Pengolahan Data

a. Analisis ABC

Dalam penelitian ini, jenis persediaan yang diteliti yaitu obat-obatan. Berdasarkan data yang diperoleh terdapat 30 jenis obat. Buat menentukan pengelompokkan obat, peneliti melakukan studi analisis $\mathrm{ABC}$ dengan mengelompokkan obat berdasarkan nilai investasinya. Berikut yaitu hasil analisis $\mathrm{ABC}$ obat berdasarkan investasi pada bulan Januari-Mei 2021.
Klasifikasi persediaan berdasarkan pemakaian dan investasi dibagi atas 3 bagian, yaitu:

- Persediaan dengan tingkat pemakaian dan investasinya tinggi dengan persen(\%) kumulatifnya 0 $70 \%$ yang disebut fast moving dengan bobot $=3$, yaitu kategori kelompok A.

- Persediaan dengan tingkat pemakaian dan investasinya sedang dengan persen(\%) kumulatifnya $71-90 \%$ yang disebut moderate dengan bobot $=2$, yaitu kategori kelompok B.

- Persediaan dengan tingkat pemakaian dan investasinya sedang dengan persen(\%) kumulatifnya 91-100\% yang disebut slow moving dengan bobot $=1$, yaitu kategori kelompok C.

Tabel 2. Pengelompokkan Metode ABC

\begin{tabular}{|l|c|c|c|}
\hline \multicolumn{1}{|c|}{ Kelompok Obat } & $\begin{array}{c}\text { Jumlah } \\
\text { Jenis Obat }\end{array}$ & Nilai Investasi(Rp) & $\begin{array}{c}\text { Persentase Nilai } \\
\text { Investasi }\end{array}$ \\
\hline Kelompok A & 13 & 6.664 .347 .164 & $70,78 \%$ \\
\hline Kelompok B & 9 & 1.717 .329 .554 & $18,24 \%$ \\
\hline Kelompok C & 8 & 1.033 .287 .310 & $10,97 \%$ \\
\hline Total & $\mathbf{3 0}$ & $\mathbf{9 . 4 1 4 . 9 6 4 . 0 2 8}$ & $\mathbf{1 0 0 \%}$ \\
\hline
\end{tabular}

Tabel di atas menunjukkan kelompok obat berdasarkan nilai investasi. Obat yang tergolong kelompok A yaitu sebanyak 13 jenis obat dengan nilai investasi sebesar Rp 6.664.347.164 atau 70,78\% dari total investasi di PT. Daya Muda Agung. Obat yang tergolong di kelompok B yaitu sebanyak 9 jenis obat dengan nilai investasi sebesar Rp 1.717.329.554 atau 18,24\% dari total investasi di PT. Daya Muda Agung. Sedangkan obat yang tergolong di kelompok $\mathrm{C}$ yaitu sebanyak 8 jenis obat dengan nilai investasi sebesar Rp 1.033.287.310 atau $10,97 \%$ dari total investasi obat di PT. Daya Muda Agung. b. Economic Order Quantity (EOQ)

Setelah diketahui jumlah permintaan obat, biaya pemesanan dan biaya penyimpanan, kemudian dilakukan perhitungan mengenai jumlah pemesanan optimum dalam setiap kali pemesanan. Berikut yakni contoh perhitungan EOQ pada obat SAMCODIN
Jumlah permintaan periode Januari $2021=4.158$ strip

Harga

$=\operatorname{Rp} 38.600$

Biaya pemesanan

Biaya penyimpanan

$=\mathrm{Rp} 1.510 .181$

$=1,16 \%$

Maka Economic Order Quantity (EOQ) yaitu

$$
\begin{aligned}
\mathrm{Q} & =\sqrt{\frac{2 x D x S}{P \times I}} \\
\mathrm{Q}^{2} & =\frac{2 \times 4.158 \times 1.510 .181}{38.600 \times 0,0116} \\
\mathrm{Q} & =5.296 \text { strip }
\end{aligned}
$$

Berdasarkan persamaan tersebut didapatkan bahwa jumlah pesanan optimal buat obat SAMCODIN yaitu 5.296 strip obat setiap kali pesan. Dengan memakai persamaan yang sama, maka setiap obat menghasilkan jumlah pesanan optimal sebagai berikut:

Tabel 3. Perhitungan Metode EOQ

\begin{tabular}{|c|l|c|c|c|c|c|c|}
\hline \multirow{2}{*}{ No } & \multirow{2}{*}{ Nama } & \multicolumn{5}{|c|}{ Jumlah Pesanan Optimum } & \multirow{2}{*}{ Total } \\
\cline { 3 - 6 } & & Jan & Feb & Mar & Apr & Mei & \\
\hline 1 & samcodin & 5296 & 6864 & 6022 & 6538 & 6494 & 31215 \\
\hline 2 & bet. obat kumur 190ml n & 1172 & 4718 & 5216 & 15481 & 15615 & 42202 \\
\hline 3 & omeprazole inj 40mg10vial & 624 & 482 & 1332 & 1055 & 471 & 3964 \\
\hline 4 & purifyng neem mask 100 ml & 8789 & 3675 & 3906 & 6018 & 4223 & 26611 \\
\hline 5 & rohto cool 7 ml & 4115 & 13716 & 21103 & 9172 & 8521 & 56627 \\
\hline 6 & counterpain cream 15 gr & 6166 & 5522 & 10611 & 2507 & 3268 & 28074 \\
\hline 7 & tempra drops 15ml new pck & 1775 & 2315 & 3276 & 2210 & 2831 & 12406 \\
\hline 8 & movibet infus 400 mg & 177 & 756 & 580 & 94 & 449 & 2056 \\
\hline 9 & sanmol syrup 60 ml & 5853 & 6349 & 7611 & 14017 & 7174 & 41005 \\
\hline 10 & betadine sol 5 ml n & 28890 & 13400 & 23954 & 23022 & 17559 & 106824 \\
\hline 11 & counterpain cream 30 gr & 3392 & 2369 & 4863 & 823 & 1596 & 13043 \\
\hline 12 & purifyng nem facewsh100ml & 2738 & 1892 & 2248 & 1684 & 4197 & 12759 \\
\hline 13 & pepzol vial 40 mg & 504 & 413 & 519 & 608 & 351 & 2395 \\
\hline
\end{tabular}




\section{c. Buffer Stock dan Reorder Point (ROP)}

Buat menentukan waktu pemesanan yang ideal buat setiap jenis obat dapat dipakai perhitungan Reorder Point (ROP). Keputusan mengenai kapan mengajukan pemesanan kembali terletak pada dua faktor, yaitu; yang pertama pertimbangan tingkat pemesanan kembali secara langsung berdasarkan pada pemakaian normal dan yang kedua pertimbangan sediaan pengaman berdasarkan derajat ketidakpastian dan tingkat pelayanan yang diminta [7]. Oleh sebab itu perlu dilakukan perhitungan mengenai buffer stock/safety stock terlebih dahulu agar dapat menentukan kapan mengajukan pemesanan kembali.
Buat menentukan buffer stock, perlu mempertimbangkan target pencapaian kerja(service level). Berikut yakni contoh perhitungan buffer stock buat obat SAMCODIN pada bulan Januari 2021.

Jumlah permintaan rata-rata(d) $=4.158 / 30$ hari $=138$ strip $\mathrm{Z}(98 \%)$

Buffer Stock (SS)

$$
=2,05
$$$$
=\mathrm{z} \times \mathrm{d} \times \mathrm{L}
$$$$
=2,05 \times 138 \times 9
$$$$
=2.557 \text { strip }
$$

Dengan memakai persamaan tersebut, maka perhitungan buffer stock buat setiap obat yaitu sebagai berikut

Tabel 4. Perhitungan Buffer Stock (SS)

\begin{tabular}{|c|l|c|c|c|c|c|}
\hline \multirow{2}{*}{ No } & \multirow{2}{*}{ Nama } & \multicolumn{5}{c|}{ Buffer Stock } \\
\cline { 3 - 7 } & & Jan & Feb & Mar & Apr & Mei \\
\hline 1 & samcodin & 2.557 & 3.266 & 2.860 & 3.097 & 3.087 \\
\hline 2 & bet. obat kumur 190ml n & 517 & 2.214 & 2.454 & 7.372 & 7.464 \\
\hline 3 & omeprazole inj 40mg10vial & 300 & 226 & 635 & 500 & 221 \\
\hline 4 & purifyng neem mask 100 ml & 4.259 & 1.718 & 1.829 & 2.836 & 1.982 \\
\hline 5 & rohto cool 7 ml & 1.898 & 6.488 & 10.047 & 4.284 & 3.986 \\
\hline 6 & counterpain cream 15 gr & 2.951 & 2.587 & 5.039 & 1.132 & 1.502 \\
\hline 7 & tempra drops 15ml new pck & 832 & 1.077 & 1.540 & 1.023 & 1.325 \\
\hline 8 & movibet infus 400 mg & 81 & 358 & 273 & 39 & 210 \\
\hline 9 & sanmol syrup 60 ml & 2.734 & 2.924 & 3.531 & 6.593 & 3.321 \\
\hline 10 & betadine sol 5 ml n & 13.812 & 6.103 & 11.183 & 10.696 & 8.104 \\
\hline 11 & counterpain cream 30 gr & 1.618 & 1.096 & 2.297 & 352 & 724 \\
\hline 12 & purifyng nem facewsh100ml & 1.290 & 859 & 1.031 & 756 & 1.969 \\
\hline 13 & pepzol vial 40 mg & 267 & 179 & 283 & 389 & 130 \\
\hline
\end{tabular}

Setelah menentukan buffer stock, maka akan dilakukan perhitungan Reorder Point(ROP). Berikut yakni contoh perhitungan Reorder Point(ROP) buat obat SAMCODIN.

$\mathrm{ROP}=(\mathrm{d} \times \mathrm{L})+\mathrm{SS}$

$=(138 \times 9)+2.546$

$=3.788$ strip

Jadi, Reorder Point (ROP) buat obat SAMCODIN yaitu 3.788 strip. Berdasarkan perhitungan tersebut, artinya pada lead time/waktu tunggu selama 9 hari dengan pemakaian rata-rata 138 , obat SAMCODIN dapat dilakukan pemesanan kembali ketika stok obat sudah mencapai 3.788 strip.

Selanjutnya, dengan memakai persamaan yang sama, maka perhitungan Reorder Point buat setiap obat yaitu sebagai berikut

Tabel 5. Perhitungan Reorder Point

\begin{tabular}{|c|l|c|c|c|c|c|}
\hline \multirow{2}{*}{ No } & \multirow{2}{*}{ Nama } & \multicolumn{5}{c|}{ Reorder Point } \\
\cline { 3 - 7 } & & Jan & Feb & Mar & Apr & Mei \\
\hline 1 & samcodin & 3.805 & 4.859 & 4.255 & 4.608 & 4.593 \\
\hline 2 & bet. obat kumur 190ml n & 769 & 3.294 & 3.651 & 10.968 & 11.104 \\
\hline 3 & omeprazole inj 40mg 10vial & 446 & 336 & 945 & 744 & 328 \\
\hline 4 & purifyng neem mask 100 ml & 6.337 & 2.556 & 2.721 & 4.219 & 2.948 \\
\hline 5 & rohto cool 7 ml & 2.824 & 9.653 & 14.947 & 6.374 & 5.930 \\
\hline 6 & counterpain cream 15 gr & 4.391 & 3.849 & 7.497 & 1.685 & 2.234 \\
\hline 7 & tempra drops 15ml new pck & 1.238 & 1.602 & 2.291 & 1.522 & 1.972 \\
\hline 8 & movibet infus 400 mg & 120 & 533 & 406 & 59 & 312 \\
\hline 9 & sanmol syrup 60 ml & 4.067 & 4.350 & 5.254 & 9.809 & 4.941 \\
\hline
\end{tabular}




\begin{tabular}{|c|l|c|c|c|c|c|}
10 & betadine sol $5 \mathrm{ml} \mathrm{n}$ & 20.549 & 9.080 & 16.638 & 15.914 & 12.057 \\
\hline 11 & counterpain cream 30 gr & 2.407 & 1.631 & 3.418 & 523 & 1.077 \\
\hline 12 & purifyng nem facewsh100ml & 1.919 & 1.278 & 1.534 & 1.125 & 2.930 \\
\hline 13 & pepzol vial $40 \mathrm{mg}$ & 397 & 266 & 421 & 578 & 193 \\
\hline
\end{tabular}

\section{A. Perbandingan Kebijakan Perusahaan}

PT. Daya Muda Agung memiliki masalah pada kelebihan pembelian jumlah obat dari permintaan konsumen sehingga menyebabkan menumpuknya stok obat dan terhentinya perputaran modal. Dengan menumpuknya stok obat dikhawatirkan stok obat tersebut akan menjadi kadaluwarsa sehingga menimbulkan kerugian buat perusahaan. Melihat hal ini perlu adanya perencanaan sebuah kebijakan baru yang dapat mengubah penentuan jumlah pemesanan menjadi lebih baik agar tidak menimbulkan penumpukan stok yang dapat merugikan perusahaan. Pada penelitian kali ini dipakai metode ABC buat mengelompokkan obat berdasarkan nilai investasinya, metode Economic Order Quantity (EOQ) buat menentukan jumlah pemesanan yang optimum, Reorder Point (ROP) buat menentukan titik pemesanan kembali, dan buffer stock buat mencegah adanya kekurangan persediaan ketika permintaan sedang naik. Berdasarkan hasil dari metode EOQ perusahaan diharuskan membuat perubahan pada kebijakan persediaan yang akan dilakukan oleh perusahaan buat melakukan pemesanan obat. Sebelumnya perusahaan telah melakukan pemesanan dengan jumlah yang sudah ditetapkan sebelumnya, dengan hasil penelitian ini diharapkan perusahaan akan mengganti jumlah pemesanan dan waktu pemesanan kembali. Berikut yaitu perbandingan kebijakan perusahaan dengan hasil penelitian

Tabel 6. Total Pembelian Existing

\begin{tabular}{|c|c|c|c|c|c|c|c|c|}
\hline \multirow{2}{*}{ No } & \multirow{2}{*}{ Nama } & \multirow{2}{*}{$\begin{array}{l}\text { Harga } \\
\text { Satuan }\end{array}$} & \multicolumn{5}{|c|}{ Pembelian Existing } & \multirow{2}{*}{ Total } \\
\hline & & & Jan & Feb & Mar & Apr & Mei & \\
\hline 1 & samcodin & 38.600 & 5.405 & 7.169 & 6.278 & 6.849 & 6.777 & 1.253 .626 .096 \\
\hline 2 & bet. obat kumur $190 \mathrm{ml} \mathrm{n}$ & 27.000 & 1.092 & 4.860 & 5.387 & 16.302 & 16.384 & 1.188 .659 .340 \\
\hline 3 & omeprazole inj 40mg10vial & 250.000 & 633 & 495 & 1.395 & 1.106 & 485 & 1.028 .357 .500 \\
\hline 4 & purifyng neem mask $100 \mathrm{ml}$ & 30.053 & 9.004 & 3.771 & 4.015 & 6.271 & 4.350 & 823.750 .025 \\
\hline 5 & rohto cool $7 \mathrm{ml}$ & 13.320 & 4.012 & 14.243 & 22.054 & 9.474 & 8.749 & 779.633 .053 \\
\hline 6 & counterpain cream $15 \mathrm{gr}$ & 21.800 & 6.239 & 5.679 & 11.061 & 2.504 & 3.297 & 627.385 .688 \\
\hline 7 & tempra drops $15 \mathrm{ml}$ new pck & 41.500 & 1.759 & 2.364 & 3.380 & 2.262 & 2.909 & 525.974 .320 \\
\hline 8 & movibet infus $400 \mathrm{mg}$ & 250.000 & 170 & 786 & 599 & 87 & 460 & 525.697 .500 \\
\hline 9 & sanmol syrup $60 \mathrm{ml}$ & 11.700 & 5.779 & 6.418 & 7.752 & 14.579 & 7.290 & 489.262 .410 \\
\hline 10 & betadine sol $5 \mathrm{ml} \mathrm{n}$ & 4.450 & 29.195 & 13.396 & 24.548 & 23.653 & 17.789 & 483.189 .544 \\
\hline 11 & counterpain cream $30 \mathrm{gr}$ & 34.900 & 3.420 & 2.406 & 5.042 & 778 & 1.589 & 461.905 .688 \\
\hline 12 & purifyng nem facewsh $100 \mathrm{ml}$ & 30.053 & 2.726 & 1.886 & 2.263 & 1.673 & 4.323 & 386.786 .618 \\
\hline 13 & pepzol vial $40 \mathrm{mg}$ & 140.000 & 564 & 393 & 621 & 860 & 285 & 381.220 .000 \\
\hline \multicolumn{8}{|c|}{ Total Biaya } & 8.955.447.782 \\
\hline
\end{tabular}

Tabel 7. Total Perhitungan EOQ

\begin{tabular}{|c|c|c|c|c|c|c|c|c|}
\hline \multirow{2}{*}{ No } & \multirow{2}{*}{ Nama } & \multirow{2}{*}{$\begin{array}{l}\text { Harga } \\
\text { Satuan }\end{array}$} & \multicolumn{5}{|c|}{ Pembelian Existing } & \multirow{2}{*}{ Total } \\
\hline & & & Jan & Feb & Mar & Apr & Mei & \\
\hline 1 & samcodin & 38.600 & 5.405 & 7.169 & 6.278 & 6.849 & 6.777 & 1.253 .626 .096 \\
\hline 2 & bet. obat kumur $190 \mathrm{ml} \mathrm{n}$ & 27.000 & 1.092 & 4.860 & 5.387 & 16.302 & 16.384 & 1.188 .659 .340 \\
\hline 3 & omeprazole inj 40mg10vial & 250.000 & 633 & 495 & 1.395 & 1.106 & 485 & 1.028 .357 .500 \\
\hline 4 & purifyng neem mask $100 \mathrm{ml}$ & 30.053 & 9.004 & 3.771 & 4.015 & 6.271 & 4.350 & 823.750 .025 \\
\hline 5 & rohto cool $7 \mathrm{ml}$ & 13.320 & 4.012 & 14.243 & 22.054 & 9.474 & 8.749 & 779.633 .053 \\
\hline 6 & counterpain cream $15 \mathrm{gr}$ & 21.800 & 6.239 & 5.679 & 11.061 & 2.504 & 3.297 & 627.385 .688 \\
\hline 7 & tempra drops $15 \mathrm{ml}$ new pck & 41.500 & 1.759 & 2.364 & 3.380 & 2.262 & 2.909 & 525.974 .320 \\
\hline
\end{tabular}




\begin{tabular}{|c|l|c|c|c|c|c|c|r|}
8 & movibet infus $400 \mathrm{mg}$ & 250.000 & 170 & 786 & 599 & 87 & 460 & 525.697 .500 \\
\hline 9 & sanmol syrup $60 \mathrm{ml}$ & 11.700 & 5.779 & 6.418 & 7.752 & 14.579 & 7.290 & 489.262 .410 \\
\hline 10 & betadine sol $5 \mathrm{ml} \mathrm{n}$ & 4.450 & 29.195 & 13.396 & 24.548 & 23.653 & 17.789 & 483.189 .544 \\
\hline 11 & counterpain cream 30 gr & 34.900 & 3.420 & 2.406 & 5.042 & 778 & 1.589 & 461.905 .688 \\
\hline 12 & purifyng nem facewsh100ml & 30.053 & 2.726 & 1.886 & 2.263 & 1.673 & 4.323 & 386.786 .618 \\
\hline 13 & pepzol vial 40 mg & 140.000 & 564 & 393 & 621 & 860 & 285 & 381.220 .000 \\
\hline \multicolumn{3}{|c|}{ Total Biaya } \\
\hline
\end{tabular}

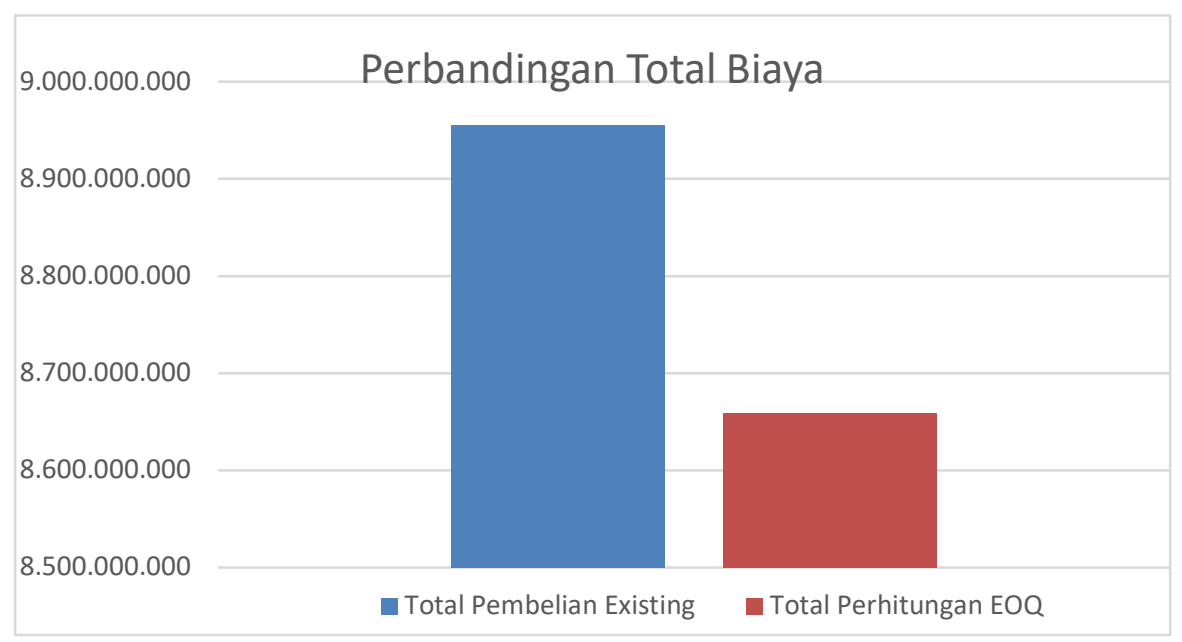

Gambar 2. Grafik Perbandingan biaya pembelian

Berdasarkan gambar 2. di atas didapatkan informasi bahwa total biaya pembelian existing dan total biaya pembelian hasil penelitian berbeda, dengan perbedaan sebesar Rp 296.141.938 yaitu total biaya pembelian hasil perhitungan EOQ lebih rendah dari total biaya pembelian existing. Dengan perbedaan tersebut maka total biaya pembelian hasil perhitungan EOQ lebih rendah dari total biaya pembelian existing yaitu sebesar $3,30 \%$.

\section{KESIMPULAN DAN SARAN}

1. Perencanaan persediaan obat pada PT. Daya Muda Agung memakai metode Economic Order Quantity (EOQ), merubah beberapa kebijakan perusahaan terhadap jumlah pemesanan obat, dengan adanya perubahan kebijakan tersebut dihasilkan jumlah pemesanan yang lebih optimal agar perusahaan mengeluarkan total biaya yang lebih rendah. Diketahui total biaya pemesanan obat dari kebijakan perusahaan yaitu sebesar Rp 8.955.447.782 sedangkan total biaya pemesanan dari hasil penelitian yaitu sebesar Rp 8.659.305.844, selisih dari total biaya tersebut yaitu sebesar Rp 296.141.938. jadi perusahaan dapat menghemat biaya persediaan sebesar 3,30\%.

2. Berdasarkan perhitungan Reorder Point (ROP) dengan mempertimbangkan buffer stock serta lead time selama 9 hari, keputusan mengenai kapan mengajukan pemesanan kembali dapat dilakukan dengan memperhatikan batas minimal persediaan obat agar tidak menyebabkan kekosongan persediaan. Obat SAMCODIN dapat dilakukan pemesanan kembali ketika stock obat sudah mencapai 3.788 strip.

\section{DAFTAR PUSTAKA}

[1] Anief, M.(2001). Manajemen Farmasi. Universitas Gajah Mada.

[2] Assauri, S.(2004). Manajemen Produksi dan Operasi(Edisi Revisi).

[3] Assauri, S.(2008). Manajemen Pemasaran Dasar Konsep dan Strategi(Edisi Revisi). PT Raja Grafinso Persada.

[4] Handoko, H. T.(1984). Dasar-Dasar Manajemen Produksi dan Operasi.

[5] Heizer, J., \& Render, B.(2010). Manajemen Operasi. Salemba Empat.

[6] Indroprasto, E. S.(2012). Analisis Pengendalian Persediaan Produk Dengan Metode EOQ Memakai Algoritma Genetika buat Mengefisiensikan Biaya Persediaan.

[7] Johns, D., \& Harding, H.(2001). Manajemen Operasi buat Meraih Keunggulan Kompetitif.

[8] Prakoso, A.(2015). Tinjauan Atas Saluran Distribusi PT Daya Muda Agung Bogor. Sekolah Tinggi Ilmu Ekonomi Kesatuan Bogor.

[9] Rangkuti, F.(2007). Manajemen Persediaan. Rajagrafindo Persada.

[10] Rudianto.(2012). Pengantar Akuntansi Adaptasi IFRS. Erlangga.

[11] Sianturi, D. R., Arvianto A.(2014). Implementasi Persediaan EOQ Multi Item dengan Mempertimbangkan Masa Deathstock pada NonKonstan Demand.

[12] Tersine, R. J.(1994). Principles of Inventory and Material Management 4th Edition. Pretince Hall International Edition.

[13] Ukirama.(2016). Pengertian, Fungsi, dan Metode Pengendalian Persediaan(Stock Control) pada Perusahaan Manufaktur. https://ukirama.com/id/blogs/pengertian-fungsi-dan-metodepengendalian-persediaan-stock-control-pada-perusahaan-manufaktur

[14] Utari, A.(2014). Cara Pengendalian Persediaan Obat Paten dengan Metode Analisis ABC Metode Economic Order Quantity(EOQ) Buffer Stock dan Reorder Point(ROP) di Unit Gudang Farmasi RS Zahirah. Universitas Islam Negeri Syarif Hidayatullah.

[15] Valentino, P. F.(2020). Perencanaan Persediaan Obat Memakai Model EOQ Multi Item. Universitas Brawijaya. 